\title{
Functional diversity of bacterioplankton assemblages in western Antarctic seawaters during late spring
}

\author{
Maria Montserrat Sala*, Laura Arin, Vanessa Balagué, Jordi Felipe, \\ Òscar Guadayol, Dolors Vaqué
}

Departament de Biologia Marina i Oceanografia, Institut de Ciències del Mar-CMIMA (CSIC), P. Marítim de la Barceloneta 37-49, 08003 Barcelona, Spain

\begin{abstract}
Functional diversity and aminopeptidase activity (AMA) in bacterial assemblages were determined in western Antarctic waters during late spring 2002. Functional diversity was assayed by the patterns of sole carbon source utilization in Biolog-ECO Microplates ${ }^{\mathrm{TM}}$ and AMA with the fluorogenic substrate leucine 7-amido-4-methylcoumarin. N-acetyl-D-glucosamine and D-cellobiose were the most used carbohydrates. This suggested that used dissolved organic carbon (DOC) was mostly of either zoo-or phytoplankton origin. Principal component analysis of the sole carbon source utilization profiles separated the samples according to salinity and temperature. This separation corresponded roughly with the 3 areas of study: Bransfield Strait (BR), Gerlache Strait (GE) and Bellingshausen Sea (BE). AMA was higher in the upper $40 \mathrm{~m}$, probably associated with the higher organic matter load. Phytoplankton biomass was the factor that accounted for the highest variance in AMA, but did not have a clear influence on functional diversity of bacterioplankton. Our findings indicate that differences in functional diversity of bacterioplankton populations in western Antarctic waters are not directly related to phytoplanktonic abundance. This suggests that bacteria could utilize other carbon sources than DOC freshly released by phytoplankton.
\end{abstract}

KEY WORDS: Bacterial activity · Functional diversity · Biolog · Aminopeptidase · Ectoenzyme · Antarctica

\section{INTRODUCTION}

Heterotrophic bacterioplankton are the dominant consumers of dissolved organic carbon (DOC) in the ocean, converting it to biomass or inorganic nutrients (Azam \& Hodson 1977, Azam et al. 1983). In cold waters, growth of marine heterotrophic bacteria can be limited by temperature and substrates (Pomeroy \& Wiebe 2001). Since Antarctic waters are characterized by high concentrations of inorganic nitrogen and phosphorus, bacterioplankton assemblages seem to be limited by DOC (Karl et al. 1991, Tupas et al. 1994, Ducklow et al. 2001). The DOC pool in aquatic environments is a complex mixture of substrates present at very low concentrations. The flux of these molecules into cells is difficult to measure with the available techniques. For this reason, indirect methods have been applied to gain some insight into the DOC molecules consumed by bacteria. The most popular approach is the determination of ectoenzymatic activities (Hoppe 1983). One such ectoenzymatic activity is leucine aminopeptidase activity (AMA), which hydrolyzes polymeric amino acids (dipeptides and polypeptides) to monomers. This enzyme plays a significant role in the carbon and nitrogen nutrition of the microbial community and provides a clue to the efficiency of organic matter consumption (Christian \& Karl 1995). AMA, for example, was the dominant ectoenzymatic activity throughout the year in the Ross Sea (Misic et al. 1998), and higher activity was detected during events of 
autotrophic production than consumption (Misic et al. 2002).

Composition of the organic matter utilized by the bacterial populations is likely to be an important regulator of the metabolic activity of bacterioplankton. Biolog Microplates ${ }^{\mathrm{TM}}$ have provided an insight into the functional diversity of bacterial populations in many ecosystems (reviewed by Preston-Mafham et al. 2002). In marine environments the Biolog approach has distinguished bacterial populations according to their metabolic capabilities depending on the origin of the organic matter available in the Californian coast (Hollibaugh 1994).

The distribution of bacterioplankton biomass and production in western Antarctica is relatively well known (Karl et al. 1996, Pedrós-Alió et al. 2002), and this allows studies of functional diversity of bacterioplankton that have not been investigated until now. We determined bacterial AMA and bacterial utilization of carbon sources in Biolog-ECO plates. We then proposed the following hypothesis: Since DOC in Antarctic waters derives mainly from primary production, we expect (1) a relationship between chl a concentration and $\mathrm{AMA}_{\text {; }}$ and (2) a key role of phytoplankton biomass in determining functional bacterial diversity according to the sole carbon source utilization patterns in the Biolog-ECO plates.

\section{MATERIALS AND METHODS}

Situation and sampling strategy. Samples were collected during the TEMPANO cruise on board of RV 'BIO-Hespérides', from 30 November to 16 December 2002. The area of study and the sampling sites are presented in Fig.1. The area includes the western basin of the Bransfield Strait (BR), the Bellingshausen Sea (BE) and the eutrophic and mesotrophic coastal region of Gerlache Strait (GE). Sampling dates, location and maximal depth for each station are listed in Table 1. Seawater samples were collected with 12 l Niskin bottles mounted on a rosette. Temperature and salinity profiles were measured with a General Oceanics MkIIIC WOCE probe provided with extra fluorescence and light transmission sensors.

Physico-chemical and biological variables. Chlorophyll a concentration was estimated fluorimetrically according to Yentsch \& Menzel (1963). A water volume of $150 \mathrm{ml}$ was filtered through a Whatman GF/F filter. Filters were kept frozen overnight in the dark and pigments were extracted in $6 \mathrm{ml}$ acetone over $24 \mathrm{~h}$. Fluorescence was measured in a Turner Designs fluorometer. Bacterial concentration was estimated by flow cytometry following the methodology described by Gasol \& Del Giorgio (2000). Samples (4.0 ml) were fixed with $0.40 \mathrm{ml}$ of a $10 \%$ paraformaldehyde and $0.5 \%$ glutaraldehyde mixture, left to fix in the dark for $10 \mathrm{~min}$, deep frozen in liquid nitrogen and then stored at $-80^{\circ} \mathrm{C}$. At the time of determination, samples were thawed and run through a FACScalibur (Becton and Dickinson) flow cytometer with laser emission of $488 \mathrm{~nm}$. Bacteria had previously been stained with $4 \mu \mathrm{l}$ of a $500 \mu \mathrm{M}$ SYTO13 (Molecular Probes) solution. Samples were run at low flow rate (about $24.5 \mu \mathrm{l} \mathrm{min}{ }^{-1}$ ) and data acquisition was in log mode over 2 min or until about 100000 events were acquired. Bacterial numbers were calculated using flow speed. Flow was calibrated with every tenth sample determining the sample volume before and after a 10 min run.

Aminopeptidase activity. AMA was determined using fluorogenic substrates (Hoppe 1983, 1993) and followed the modifications described in Sala et al. (2001). Briefly, $0.1 \mathrm{ml}$ leucine 7 -amido-4-methylcoumarin was added at saturating
Fig. 1. Location of stations in the 3 regions of study sampled during TEMPANO cruise 
Table 1. Characteristics of the stations sampled during TEMPANO cruise in austral late spring 2002. Stations were named according to the 3 different zones visited: Bransfield Strait (BR), Gerlache Strait (GE), Bellingshausen Sea (BE), and the number of sampling stations

\begin{tabular}{|lcccc|}
\hline Stn & Date & Longitude & Latitude & $\begin{array}{c}\text { Maximum } \\
\text { depth (m) }\end{array}$ \\
\hline BR1 & 30 Nov & $63^{\circ} 23^{\prime} 34^{\prime \prime} \mathrm{W}$ & $60^{\circ} 03^{\prime} 15^{\prime \prime} \mathrm{S}$ & 180 \\
BR2 & 03 Dec & $62^{\circ} 44^{\prime} 38^{\prime \prime} \mathrm{W}$ & $59^{\circ} 10^{\prime} 44^{\prime \prime} \mathrm{S}$ & 1472 \\
GE3 & 05 Dec & $64^{\circ} 23^{\prime} 30^{\prime \prime} \mathrm{W}$ & $62^{\circ} 04^{\prime} 24^{\prime \prime} \mathrm{S}$ & 916 \\
GE4 & 07 Dec & $64^{\circ} 47^{\prime} 30^{\prime \prime} \mathrm{W}$ & $63^{\circ} 06^{\prime} 57^{\prime \prime} \mathrm{S}$ & 352 \\
BE5 & 09 Dec & $65^{\circ} 57^{\prime} 29^{\prime \prime} \mathrm{W}$ & $66^{\circ} 48^{\prime} 54^{\prime \prime} \mathrm{S}$ & 225 \\
BE6 & 11 Dec & $66^{\circ} 13^{\prime} 25^{\prime \prime} \mathrm{W}$ & $68^{\circ} 17^{\prime} 51^{\prime \prime} \mathrm{S}$ & 359 \\
GE7 & 14 Dec & $64^{\circ} 56^{\prime} 14^{\prime \prime} \mathrm{W}$ & $63^{\circ} 20^{\prime} 09^{\prime \prime} \mathrm{S}$ & 250 \\
GE8 & 16 Dec & $63^{\circ} 43^{\prime} 33^{\prime \prime} \mathrm{W}$ & $61^{\circ} 27^{\prime} 56^{\prime \prime} \mathrm{S}$ & 736 \\
\hline
\end{tabular}

concentrations (200 $\mu \mathrm{M}$ final concentration) to $0.9 \mathrm{ml}$ samples. Fluorescence in the samples was measured in a Shimadzu RF-5301 PC spectrofluorimeter at $365 \mathrm{~nm}$ excitation and $446 \mathrm{~nm}$ emission wavelengths immediately after addition of the substrate. Fluorescence was measured again after incubation at $2{ }^{\circ} \mathrm{C}$ between 4 and $5 \mathrm{~h}$. Increase in fluorescence units during the incubation time was converted into activity with a standard curve of the end product of the reaction, 7-amino-4methylcoumarin.

Biolog plates. Biolog-ECO Microplates ${ }^{\mathrm{TM}}$ were used to determine differences in community-level physiological profiles. Biolog-ECO plates (Biolog) are microtiter plates in which each well contains an individual carbon source as well the redox tetrazolium violet in a dried-film form. As bacteria grow and oxidize each substrate, reduced nicotinamide adenine dinucleotide (NADH) is formed. The reduced product, insoluble formazan, appears as a purple colour that can be quantified photometrically. The resultant patterns are a function of the original community inoculated into the wells. Biolog-ECO plates contain 31 carbon sources in triplicates. Samples for Biolog were collected from 6 depths in Stns BR1, BR2, GE3, GE4 and BE6, and from the 2 upper depths in Stns BE5, GE7, and GE8. After inoculation of $150 \mu \mathrm{l}$ in each well, samples were incubated in the dark at $2^{\circ} \mathrm{C}$ over $10 \mathrm{~d}$. After incubation, samples were kept at $-20^{\circ} \mathrm{C}$ until further analysis. Previous tests showed that freezing the samples did not have an effect on the absorbance. Changes in colour development were measured using a spectrophotometric microplate reader (ELX800 BIOTEK Instruments) at a wavelength of $590 \mathrm{~nm}$.

The color development for each plate was expressed as average substrate color development (ASCD). This is similar to average well colour development (AWCD) suggested by Garland \& Mills (1991) to eliminate biases caused by differences in the bacterial abun- dance of the inoculum, but modified for the triplicate wells per substrate in the Biolog-ECO plate. ASCD $=\Sigma$ $[(R-C) / 31]$, where $R$ is the average of the absorbance of the 3 wells of a substrate and $C$ is the average of the absorbance of the 3 control wells (without a carbon source). To reduce the influence of the density of the inocculum and allow comparison among plates, the absorbance value for each well was transformed according to Garland \& Mills (1991) by substracting the average absorbance of the 3 control wells from each average absorbance per substrate, i.e. $R-C$, and then dividing this value by the ASCD. Before the analysis, negative responses were set to zero.

Principal component analysis. In order to determine the differences among patterns of sole carbon utilization profiles, principal component analysis (PCA) was performed with the software Statistica v.6.0. PCA is a statistical tool to reduce the number of variables in a data matrix. The variables are projected onto new axes or principal components (PC) which account for a certain amount of variance of the sample. Since the first 2 PCs account for the highest variance, they are generally the scores that are plotted.

\section{RESULTS}

We distinguished 3 different regions in our area of sampling: BR, GE and BE (Fig. 1). Coordinates, date of sampling and maximal depth of the Stns are shown in Table 1. Stn GE8 was geographically located at the border between BR and GE. However, according to the temperature and salinity profiles, we decided to include it in the GE.

\section{Environmental parameters}

Temperatures in GE (Fig. 2) were clearly higher than in the other regions $\left(-0.75\right.$ to $\left.0.36^{\circ} \mathrm{C}\right)$. The lowest temperatures were recorded in the Bellingshausen Sea $\left(-1.72\right.$ to $\left.-1.48^{\circ} \mathrm{C}\right)$. Changes in temperature with depth were minor compared to differences among stations.

The 3 southern stations (GE7, BE5 and BE6) showed the lowest salinities ( $<34$ PSU) with increasing values with depth. At Stns BR1, BR2, GE3, GE4 and GE7 salinities were $>34$ PSU and showed homogenous profiles with depth.

The 8 stations could be divided according to their temperature (above or below $-1{ }^{\circ} \mathrm{C}$ ) and salinity (above or below $34 \mathrm{PSU}$ ), which was utilized for the PCA analysis as later described below. Chlorophyll a concentration was generally higher in the upper $50 \mathrm{~m}$ (Fig. 2) (0.37 to $1.87 \mu \mathrm{g} \mathrm{l}^{-1}$ ), than below $60 \mathrm{~m}$ 


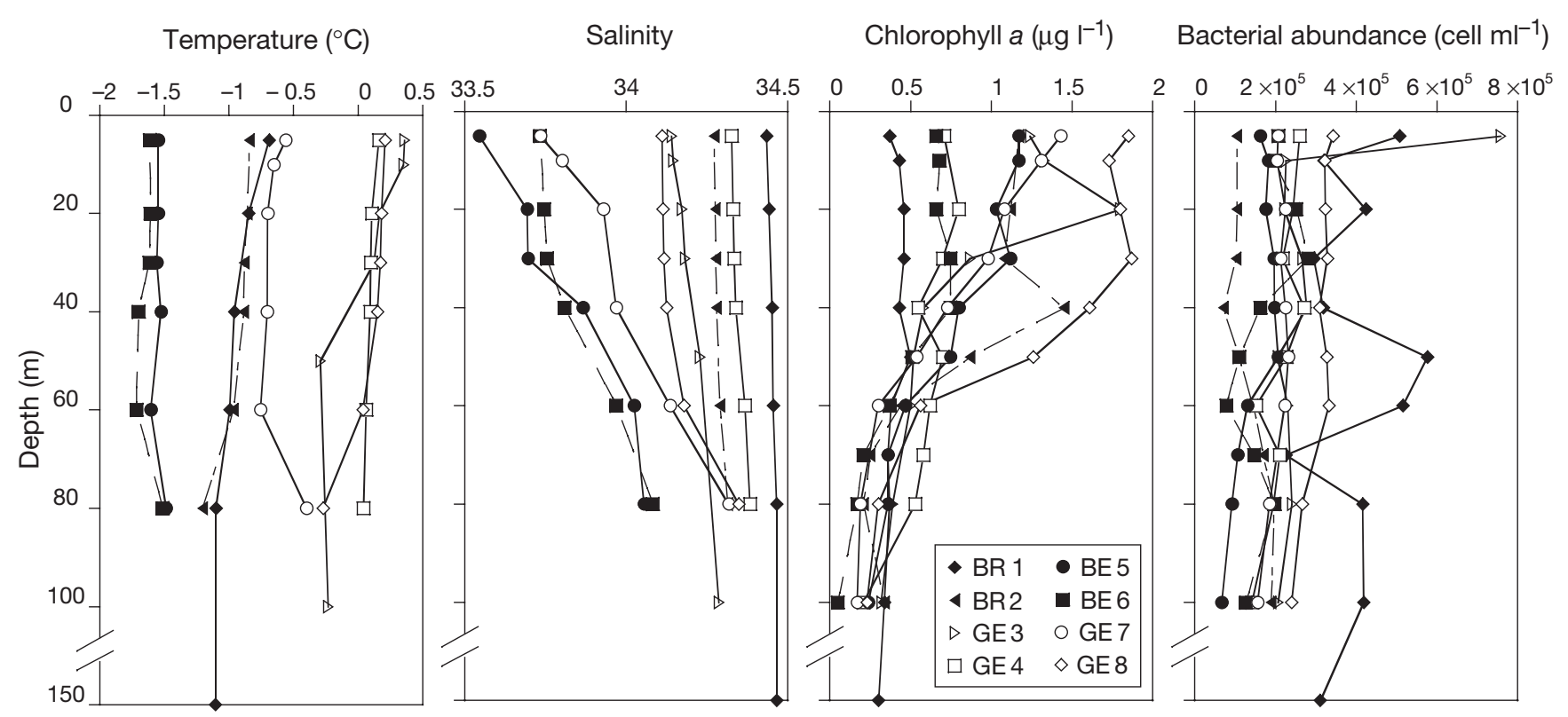

Fig. 2. Vertical profiles of temperature, salinity, chl a concentration and bacterial abundance at the 8 stations studied

(0.17 to $\left.0.56 \mu \mathrm{g}^{-1}\right)$. The highest concentrations were observed at the 3 GE stations: GE3, GE7 and GE8, and the lowest in BR1. Bacterial abundance did not change very much with depth (Fig. 2). The highest concentrations were found at BR1 and the lowest at BR2. Neither chl a nor bacterial concentration profiles showed clear differences among the studied areas.

\section{Aminopeptidase activity (AMA)}

Vertical profiles of AMA showed higher values in the upper $40 \mathrm{~m}$ (161 to $506 \mathrm{nmol} \mathrm{l}^{-1} \mathrm{~h}^{-1}$ ) than below (Fig. 3). Two stations in GE (GE8 and GE3) showed the highest activity. Differences in AMA among the 3 areas were found (ANOVA, $\mathrm{p}=0.015, \mathrm{n}=48$ ), and a post hoc Tukey's HSD test revealed only differences between BE and GE ( $p=0.013)$, with lowest activities in BE and highest in GE. AMA was positively correlated with chl a concentration $(\mathrm{n}=48, \mathrm{r}=0.90, \mathrm{p}<0.001)$, temperature ( $\mathrm{n}=48, \mathrm{r}=0.56, \mathrm{p}<0.001)$ and bacterial concentration ( $\mathrm{n}=48, \mathrm{r}=0.34, \mathrm{p}<0.05$ ), and negatively correlated with total inorganic nitrogen concentration $(\mathrm{n}=$ $48, \mathrm{r}=0.58, \mathrm{p}<0.001)$.

\section{Patterns of sole carbon source utilization}

Utilization of sole carbon sources (Table 2) showed that phenolic compounds (2-hydroxy benzoic acid and 4-hydroxy benzoic acid) were the most intensely used substrates in these Antarctic waters. Among the 10 substrates with higher utilization, there were 3 polymers: tween 40, glycogen and $\alpha$-cyclodextrin, 2 amines: phenylethylamine and putrescine, 2 carbohydrates: N-acetyl-D-glucosamine and D-cellobiose and 1 amino acid: L-phenylalanine. Five carbon sources were not utilized in any sample: D-galactonic acid $\gamma$-lactone, I-erythritol, L-arginine, L-asparagine and D-malic acid.

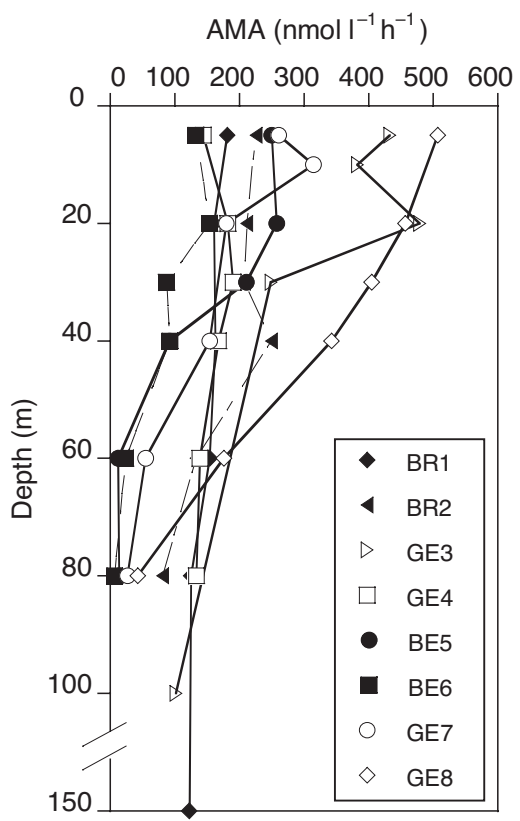

Fig. 3. Aminopeptidase (AMA) activity in the 8 stations studied 
Table 2. Mean of the average substrate color development (ASCD) of the samples obtained in the western Antarctic waters $(\mathrm{n}=36, \mathrm{SE}=$ standard error). The following substrates did not show color development: D-galactonic acid $\gamma$-lactone, I-erythritol, L-arginine, L-asparagine and D-malic acid

\begin{tabular}{|c|c|c|}
\hline Substrate & Mean utilization & SE \\
\hline 2-Hydroxy Benzoic acid & 6.59 & 0.77 \\
\hline 4-Hydroxy Benzoic acid & 3.79 & 0.49 \\
\hline Tween 40 & 2.85 & 0.45 \\
\hline L-Phenylalanine & 2.42 & 0.32 \\
\hline N-Acetyl-D-Glucosamine & 2.10 & 0.34 \\
\hline D-Cellobiose & 2.08 & 0.41 \\
\hline Glycogen & 1.82 & 0.38 \\
\hline Phenylethylamine & 1.43 & 0.34 \\
\hline$\alpha$-Cyclodextrin & 1.27 & 0.25 \\
\hline Putrescine & 1.07 & 0.27 \\
\hline$\beta$-Methyl-D-Glucoside & 0.86 & 0.25 \\
\hline D, L- $\alpha$-Glycerol Phosphate & 0.83 & 0.18 \\
\hline$\gamma$-Hydroxibutyric acid & 0.65 & 0.18 \\
\hline Glycyl-L-Glutamic acid & 0.60 & 0.22 \\
\hline Piruvic Acid Methyl ester & 0.46 & 0.25 \\
\hline Itaconic acid & 0.41 & 0.13 \\
\hline Tween 80 & 0.36 & 0.12 \\
\hline Glucose-1-Phosphate & 0.30 & 0.09 \\
\hline D-Glucosaminic acid & 0.22 & 0.08 \\
\hline D-Mannitol & 0.22 & 0.13 \\
\hline$\alpha$-Ketobutyric acid & 0.21 & 0.08 \\
\hline$\alpha$-D-Lactose & 0.14 & 0.06 \\
\hline L-Threonine & 0.09 & 0.05 \\
\hline L-Serine & 0.08 & 0.08 \\
\hline D-Xylose & 0.02 & 0.02 \\
\hline D-Galacturonic acid & 0.02 & 0.02 \\
\hline
\end{tabular}

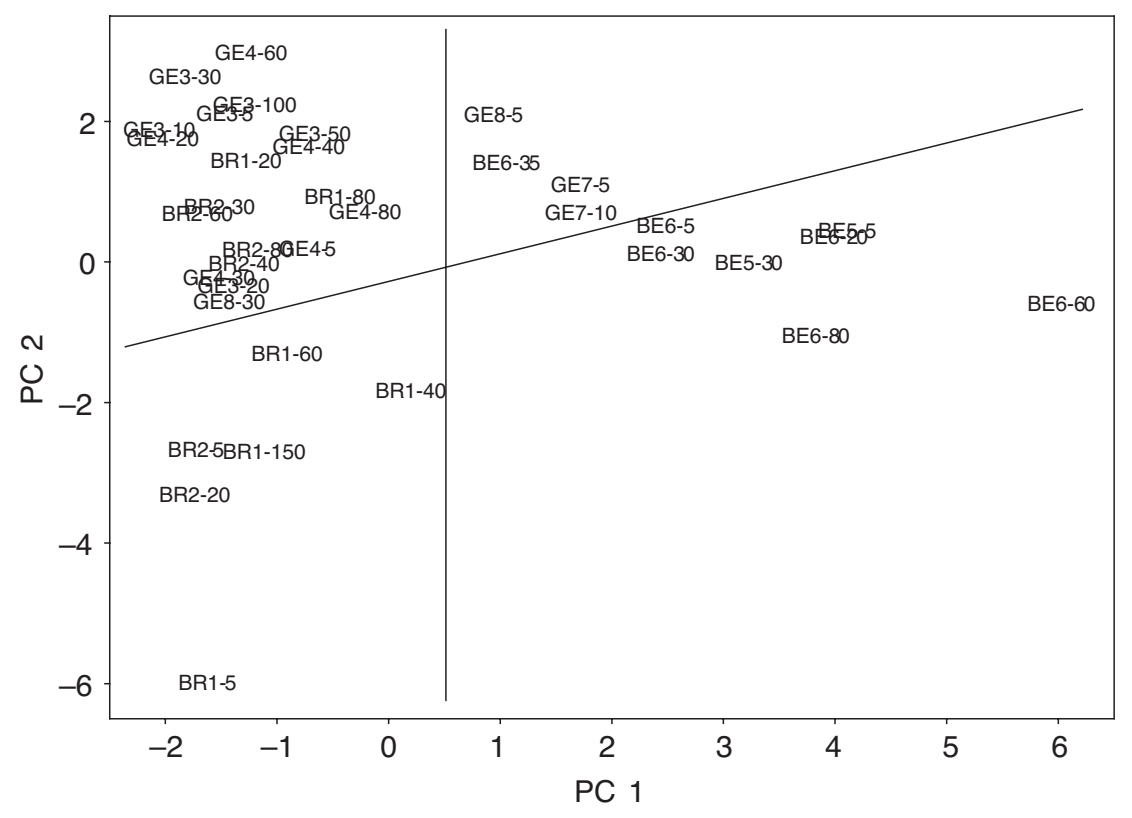

Fig. 4. PC1 plotted against PC2 for Biolog data collected. Names denote station and depth of sampling

\section{Principal component analysis}

PCA was performed on the 36 samples of the 8 stations (Fig. 4). PC1 accounted for $17 \%$ of the variance and PC2 for $12 \%$. Multiple regression analysis showed that temperature and salinity together accounted for $65 \%$ of the variance in PC1 ( $p=0.0001)$ and $44 \%$ of the variance in PC2 ( $p=0.0289)$. Temperature and salinity plots (Fig.1) allowed separation of the stations according to their salinity and temperature. Stations with low temperatures $\left(<-1^{\circ} \mathrm{C}\right)$ were BE5 and BE6, while all BR and GE stations had high temperatures $\left(>-1^{\circ} \mathrm{C}\right)$. Stations could also be differentiated according to their salinity. Stations with high salinity (>34 PSU) were BR1, BR2, GE3, GE4, GE8, and lower salinity (<34 PSU) was found in the 3 southernmost stations (BE5, BE6, GE7). Stn GE7 had a salinity of $>34$ PSU at depths $>60 \mathrm{~m}$, but since only the 2 upper depths of the stations were used for the Biolog assay, the station was still included in the low salinity group. A reexamination of Fig. 4 with this information shows a separation of the samples by salinity and temperature (Fig. 5). Generally, samples with temperatures $<-1^{\circ} \mathrm{C}$ were situated below samples with temperatures $>-1^{\circ} \mathrm{C}$. Considering salinity, samples with salinities $>34$ PSU were located on the left of the figure, while samples with salinities <34 PSU were located on the right.

The separation of samples in PC space can be related to differences in carbon source utilization by examining the correlation of the PC to the original variables. The most important carbon sources in differentiating among our populations were defined as those that had at least half of their variance explained by PC1 or PC2 (Table 3). PCA analysis aggregated the samples into 3 areas that very roughly corresponded to the areas of sampling and that were characterized by markedly different temperature and salinity. Group 1 was formed mainly by the 3 southern stations: BE5, BE6 and GE7, which were characterized by low salinities and low temperatures. These stations showed a lower utilization of N-acetyl-D-glucosamine, D-cellobiose, glycyl-L-glutamic acid, Lserine and L-threonine than the others. Group 2 was formed by samples from BR, and had low temperatures but higher salinities and most of them were grouped due to their higher 2-hydroxy benzoic acid utilization and low glucose-1- 
Table 3. Pearson correlation coefficients (r) for scores of the first 2 principal components (PC1 and PC2) from the 35 samples obtained in western Antarctic waters and the average substrate color development (ASCD) for each substrate. Only substrates with an $r>0.5$ are shown $(p<0.005)$

\begin{tabular}{|lclc|}
\hline PC1 & & PC2 & \\
Substrate & $\mathrm{r}$ & Substrate & $\mathrm{r}$ \\
\hline Glucose-1-Phosphate & 0.86 & N-Acetyl-D-Glucosamine & -0.72 \\
$\alpha$-D-Lactose & 0.84 & D-Cellobiose & -0.69 \\
Tween 80 & 0.76 & Glycyl-L-Glutamic acid & -0.63 \\
D-Glucosaminic acid & 0.73 & L-Serine & -0.60 \\
D-Galacturonic acid & 0.58 & L-Threonine & -0.53 \\
2-Hydroxy Benzoic acid & -0.57 & & \\
-Hydroxibutyric acid & 0.51 & & \\
\hline
\end{tabular}

al. 2002, Vaqué et al. 2002), in which the focus was on prokaryotic biomass, activity, production and mortality. However, none of these studies has addressed functional diversity of bacterioplankton. Our study has shown different functional diversity of the bacterioplankton assemblages in the 3 areas of study.

Garland \& Mills (1991) first proposed the use of Biolog plates to assess functional diversity of microorganisms in environmental samples, based on the patterns of community-level sole-carbon source utilization profiles. In spite of the drawbacks of the approach reviewed by Pre-

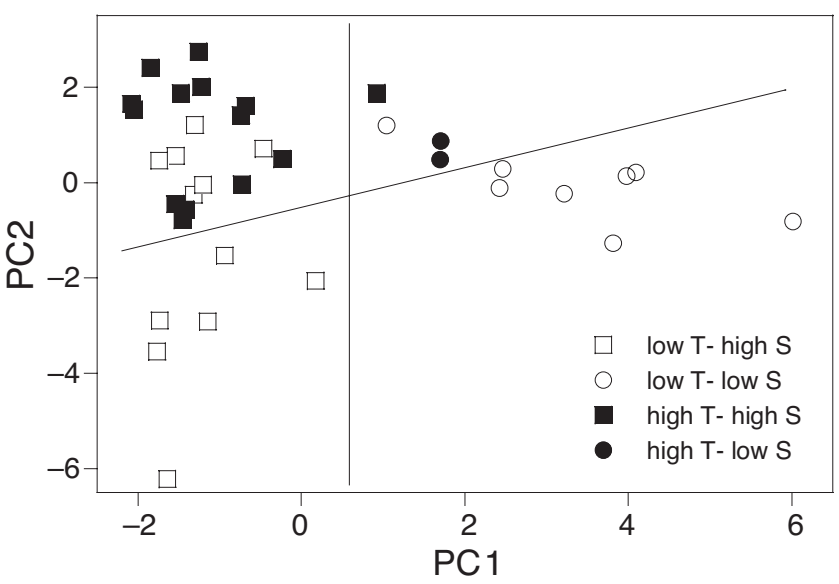

Fig. 5. Score plot of PC1 against PC2 of Biolog-Eco data obtained from samples. Samples are labelled according to salinity (S) (>34 or $<34$ PSU) or temperature (T) $(>-1$ or $<-1^{\circ} \mathrm{C}$ ). See legend for description of symbols. Line was drawn by eye to suggest a general separation of data

phosphate, $\alpha$-D-lactose, tween 80, D-glucosaminic acid and $\gamma$-hydroxybutiric acid. Group 3 contained samples taken in Stns GE3, GE4 and GE8, which had high salinities and high temperatures.

Chlorophyll a concentration was not correlated with PC1 ( $p=0.638)$ and PC2 ( $p=0.408)$. Utilization of only 2 carbon sources showed significant correlation with chl a: negative with threonine $(p=0.032)$ and positive with piruvic acid methyl esther $(p=0.001)$.

\section{DISCUSSION}

Microbial ecology in western Antarctic waters has been studied in several cruises such as the RACER program (Karl et al. 1991, Bird \& Karl 1999) reviewed by Karl (1991, 1993), or the FRUELA cruises (Guixa-Boixereu et al. 2002, Moran \& Estrada 2002, Pedrós-Alió et
ston-Mafham et al. (2002), Biolog plates have been shown to be a useful tool to detect differences in functional diversity of microbial populations in several aquatic environments such as lakes (Grover \& Chrzanowski 2000), rivers (Sinsabaugh \& Foreman 2001), estuaries (Schultz \& Ducklow 2000) and the sea (Hollibaugh 1994).

One of the drawbacks of the Biolog approach is that the substrates in the Biolog plates are not necessarily representative of the substrates available in nature (Konopka et al. 1998). In order to minimize this problem we chose the Biolog-ECO plates, which have more ecoloically relevant structurally diverse compounds that are more appropriate for microbial analysis than the most commonly used Biolog-GN plates (Choi \& Dobbs 1999, Preston-Mafham et al. 2002). The number of substrates is lower in the Biolog-ECO than in the Biolog-GN plates, but Hitzl et al. (1997) suggested that the use of a reduced set of discriminating carbon sources with a higher number of replicates in each plate would be a better approach for statistical purposes. Biolog-ECO plates have been used for aquatic studies on a few occasions (Sinsabaugh \& Foreman 2001, Tam et al. 2003).

Many of the substrates in the Biolog-ECO plates, especially carbohydrates (Kirchman et al. 2001) and amino acids (Hubberten et al. 1995), are known to occur in Antarctic waters, The 2 most utilized carbohydrates in our environment were N-acetyl-D-glucosamine and cellobiose. N-acetyl-D-glucosamine is one of the largest pools of amino sugars in the ocean and is a structural component in chitin and bacterial peptidoglycan and lipopolysaccharides that can be taken up by a large number of bacterial isolates (Rieman \& Azam 2002). Chitinolytic bacteria are common in aquatic environments (Sala \& Güde 2004), and since chitin is found in the exoeskeleton of krill and other zooplankters, N-acetyl-D-glucosamine might be a significant carbon source in Antarctic waters. The second highly used carbohydrate, D-cellobiose, is a disaccha- 
ride of glucose generated by hydrolysis of cellulose and therefore found in phytoplankton cell walls. The large contribution of phytoplankton to the DOC pool in Antarctic waters might explain the considerably high bacterial utilization of cellobiose in our area of study.

The 2 more utilized carbon sources were phenolic compounds. Phenolic compounds can be found in lignin and have an origin in vascular plants, being therefore allochthonous for the Antarctic environment. However, Grannas et al. (2004) have recently found phenolic compounds in snow-phase organic matter in the Arctic, suggesting deposition of atmospheric particulate organic matter containing vascular tissue. Another highly utilized carbon source was tween 40 . Tan (1997) found also that all strains isolated from Arctic and Antarctic waters could utilize the polyol tween 40. He suggested that polyols are accumulated by seaice algae in order to tolerate low temperatures and high salinities (Wynn-Williams 1990).

Five carbon sources were not metabolized in any sample: D-galactonic acid $\gamma$-lactone, I-erythritol, L-arginine, L-asparagine and D-malic acid. Similarly, Tan \& Rüger (1999) found that none of the 104 Antarctic bacterial isolates could metabolize D-galactonic acid $\gamma$-lactone. Only few of the isolates could metabolize Ierithritol, and L-asparagine was used by around $50 \%$ of the isolates. Both L-arginine and D-malic acid are not included in the Biolog-GN plates used by Tan \& Rüger (1999), so comparison with our results was not possible.

Schultz \& Ducklow (2000) found that salinity and temperature were the main factors driving changes in bacterial diversity in the York River Estuary. These 2 parameters defined the 3 different water zones but probably reflected the different quality of the organic matter available and diverse composition of the bacterial assemblages. A wide range of compounds, including simple sugars and amino acids, may be released by phytoplankton cells (Anderson \& Williams 1998). Kirchman et al. (2001) observed some dissolved combined neutral sugars apparently having survived for 8 mo following the phytoplankton bloom. Persistence of such compounds could be an indirect indication of stability in the molecular composition of DOM in Antarctic waters and might provide an explanation on the minor role of chl a on determining the patterns in substrate utilization among the studied areas.

\section{Aminopeptidase activity (AMA)}

AMA plays a significant role in the carbon and nitrogen nutrition of the microbial community. The values of AMA found in our study ( 7 to $506 \mathrm{nmol} \mathrm{l}^{-1}$ $\mathrm{h}^{-1}$ ) are higher than values previously found in GE (4 to $113 \mathrm{nmol} \mathrm{l}^{-1} \mathrm{~h}^{-1}$ ) (Christian \& Karl 1992) or in other antarctic or subantarctic areas (see Table 3 in Misic et al. [2002]) but comparable to ranges in North Atlantic Ocean (Davey et al. 2001). Higher AMA in the upper $40 \mathrm{~m}$ (161 to $506 \mathrm{nmol} \mathrm{l}^{-1} \mathrm{~h}^{-1}$ ) was detected, as has been reported for several marine areas (Caruso \& Zaccone 2000, Davey et al. 2001) and also for the GE (Christian \& Karl 1992), where maximum AMA was greatest in the mixed layer $(<20 \mathrm{~m})$. The relatively higher AMA in upper layers of our area of study might be associated with the greater organic load at those depths.

Chlorophyll a concentration, temperature, total inorganic nitrogen (TIN) and bacterial concentrations were the 4 main factors with possible effects on AMA. The high TIN concentrations (24 to $36 \mu \mathrm{M}$ ) in our area of study suggest that microorganisms were not limited by $\mathrm{N}$ in spite of the negative correlation between TIN and AMA. A multiple regression with temperature, chl $a$, TIN and bacterial concentration showed that chl $a$ and bacterial concentration accounted for most of the variability in AMA (91\%, data not shown). Since aminopeptidase is partly a constitutive enzyme, this may partly explain the correlation with bacterial abundance. However, the factor that accounted for the highest variability in AMA was chlorophyll a concentration. Although aminopeptidase has been detected in some dinoflagellates (Stoecker \& Gustafson 2003), phytoplanktonic contribution to AMA in Antarctic waters was small, and most of the activity was associated with the bacterial size fraction (Christian \& Karl 1992). It is therefore likely that AMA was not due to phytoplanktonic enzymatic activity, but instead bacterial AMA was enhanced by the DOC released by phytoplankton. Donachie et al. (1997) found, similar to our observations, increased levels of AMA accompanying a phytoplankton bloom in the coastal zone around the Antarctic Peninsula. In the Southern Ocean, where allochthonous inputs of organic matter are almost negligible (Bird \& Karl 1999), organic matter released by phytoplankton may be an important substrate for bacterial growth (Larsson \& Hagström 1982).

\section{Aminopeptidase and BIOLOG}

No correlation was found between the utilization of amino acids in the Biolog plates and AMA activity. This is probably because interpretation of the results of both measurements differs. Whereas AMA gives a measurement of bacterial activity, the sole carbon source utilization patterns indicate the degree of utilization of amino acids of the carbon sources tested. AMA is therefore more related to the quantity, and Biolog to 
the quality, of the organic matter available. Sinsabaugh \& Foreman (2001) also found different responses between AMA and utilization of amino acids in the Biolog plates, and suggested that Biolog plates are based on a culture response, whereas AMA is more directly linked to the mechanisms of the in situ DOM processing.

\section{CONCLUSION}

This is the first study reporting bacterial utilization of sole carbon sources in western Antarctica using Biolog plates. N-acetyl-D-glucosamine and D-cellobiose were the most frequently used carbohydrates. Three areas could be distinguished according to the functional diversity of bacterioplankton, which corresponded roughly with the different hydrographic areas of study characterized by different salinity and temperatures: BR, GE and BE. Phytoplankton abundance had a strong influence on AMA but not on the communitylevel physiological profiles observed, suggesting that bacterioplankton in western Antarctic waters might utilize other carbon sources than DOC freshly released by phytoplankton.

Acknowledgements. This study was funded by grant TEMPANO (REN2001-0588/ANT) from the Spanish Ministry of Science and Technology (MCyT). We thank the crew of the RV 'BIO-Hespérides' and the members of the Unitat de Tecnologia Marina for their help during the cruise. We thank Mariona Segura for kindly providing nutrient data, Laia Font and Leticia Albert for technical assistance, and Pep Gasol, Carlos Pedrós-Alió and Jarone Pinhassi for valuable comments on the manuscript. We would like also to thank J. P. Grover and 2 anonymous reviewers for their helpful and detailed comments and corrections.

\section{LITERATURE CITED}

Anderson TR, Williams PJ Le B (1998) Modelling the seasonal cycle of dissolved organic carbon at station E1 in the English Channel. Estuar Coast Shelf Sci 46:93-109

Azam F, Hodson RE (1977) Size distribution and activity of marine microheterotrophs. Limnol Oceanogr 22:492-501

Azam F, Fenchel T, Field JG, Gray JS, Meyer-Reil LA, Thingstad F (1983) The ecological role of water-column microbes in the sea. Mar Ecol Prog Ser 10:257-263

Bird DF, Karl DM (1999) Uncoupling of bacteria and phytoplankton during the austral spring bloom in Gerlache Strait, Antarctic Peninsula. Aquat Microb Ecol 19:13-27

Caruso G, Zaccone R (2000) Estimates of leucine aminopeptidase activity in different marine and brackish environments. J Appl Microbiol 89:951-959

Choi KH, Dobbs FC (1999) Comparison of two kinds of Biolog microplates (GN and ECO) in their ability to distinguish among aquatic microbial communities. J Microbiol Methods 36:203-213

Christian JR, Karl DM (1992) Exocellular enzyme activities in Gerlache Strait, Antarctica. Antarct J US 27:170-171
Christian JR, Karl DM (1995) Bacterial ectoenzymes in marine waters: activity ratios and temperature responses in three oceanographic provinces. Limnol Oceanogr 40:1042-1049

Davey KE, Kirby RK, Turley CM, Weightman AJ, Fry JC (2001) Depth variation of bacterial extracellular enzyme activity and population diversity in the northeastern North Atlantic Ocean. Deep-Sea Res II 48:1003-1017

Donachie SP, Tupas LM, Carrillo CJ, Karl DM, Christian JR (1997) A cross-site study of microbial ectoenzyme activities and regulation: preliminary results from the Palmer long-term ecological research component. Antarct J US 32:148-151

Ducklow H, Carlson CA, Church M, Kirchman DL, Smith D, Steward G (2001) The seasonal development of the bacterioplankton bloom in the Ross Sea, Antarctica, 1994-1997. Deep-Sea Res II 48:4199-4221

Garland JL, Mills AL (1991) Classification and characterization of heterotrophic microbial communities on the basis of patterns of community-level sole-carbon-source utilization. Appl Environ Microbiol 57:2351-2359

Gasol JM, Del Giorgio PA (2000) Using flow cytometry for counting natural planktonic bacteria and understanding the structure of planktonic bacterial communities. Sci Mar 64:197-224

Grannas AM, Shepson PB, Filley TR (2004) Photochemistry and nature of organic matter in Arctic and Antarctic snow. Global Biochem Cycles 18:1-10

Grover JP, Chrzanowski TH (2000) Seasonal patterns of substrate utilization by bacterioplankton: Case studies in four temperate lakes of different latitudes. Aquat Microb Ecol 23:41-54

Guixa-Boixereu N, Vaqué D, Gasol JM, Sánchez-Cámara J, Pedrós-Alió C (2002) Viral distribution and activity in Antarctic waters. Deep-Sea Res II 49:827-845

Hitzl W, Rangger A, Sharma S, Insam H (1997) Separation power of the 95 substrates of the BIOLOG system determined in various soils. FEMS Microbiol Ecol 22:167-174

Hollibaugh JT (1994) Relationship between thymidine metabolism, bacterioplankton community metabolic capabilities, and sources of organic matter. Microb Ecol 28:117-131

Hoppe HG (1983) Significance of exoenzymatic activities in the ecology of brackish water: Measurements by means of methylumbelliferyl-substrates. Mar Ecol Prog Ser 11: 299-308

Hoppe HG (1993) Use of fluorogenic model substrates for extracellular enzyme activity (EEA) measurement of bacteria. In: Kemp PF, Sherr BF, Sherr EB, Cole JJ (eds) Handbook of methods in aquatic microbial ecology. Lewis Publishers, Boca Raton, FL, p 423-431

Hubberten U, Lara RJ, Kattner G (1995) Refractory organic compounds in polar waters: relationship between humic substances and amino acids in the Arctic and Antarctic. J Mar Res 53:137-149

Karl DM (1993) Microbial processes in the Southern Oceans. In: Friedman EI (ed) Antarctic Microbiology. Wiley-Liss, New York, p 1-63

Karl DM, Holm-Hansen O, Taylor GT, Bird DF (1991) Microbial biomass and productivity in the Western Bransfield Strait, Antarctica, during the 1986-1987 austral summer. Deep-Sea Res I 38:1029-1055

Karl DM, Christian JR, Dore JR, Letelier RM (1996) Microbiological oceanography in the region west of the Antarctic Peninsula: microbial dynamics, nitrogen cycle and carbon flux. In: Ross RM, Hoffmann EE, Quetin LB (eds) Foundations for ecological research west of the Antarctic Peninsula. American Geophysical Union, Washington, DC, p 303-332 Kirchman DL, Meon B, Ducklow HW, Carlson CA, Hansell 
DA, Steward GF (2001) Glucose fluxes and concentrations of dissolved combined neutral sugars (polysaccharides) in the Ross Sea and Polar Front Zone, Antarctica. Deep-Sea Res II 48:4179-4197

Konopka A, Oliver L, Turco RFJ (1998) The use of carbon substrate utilization patterns in environmental and ecological microbiology. Microb Ecol 35:103-115

Larson U, Hagström $\AA$ (1982) Fractionated phytoplankton primary production, exudate release and bacterial production in a Baltic eutrophication gradient. Mar Biol 52: 199-206

Misic C, Povero P, Fabiano M (1998) Relationship between ectoenzymatic activity and availability of organic substrates (Ross Sea, Antarctica): an experimental approach. Polar Biol 20:367-376

Misic C, Povero P, Fabiano M (2002) Ectoenzymatic ratios in relation to particulate organic matter distribution (Ross Sea, Antarctica). Microb Ecol 44:224-234

Morán XAG, Estrada M (2002) Phytoplanktonic DOC and POC production in the Bransfield and Gerlache Straits as derived from kinetic experiments of ${ }^{14} \mathrm{C}$ incorporation. Deep-Sea Res II 49:769-786

Pedrós-Alió C, Vaqué D, Guixa-Boixereu N, Gasol JM (2002) Prokaryotic plankton biomass and heterotrophic production in western Antarctic waters during the 1995-1996 Austral summer. Deep-Sea Res II 49:805-825

Pomeroy LR, Wiebe WL (2001) Temperature and substrates as interactive limiting factors for marine heterotrophic bacteria. Aquat Microb Ecol 23:187-204

Preston-Mafham J, Boddy L, Randerson PF (2002) Analysis of microbial community functional diversity using solecarbon-source utilisation profiles - a critique. FEMS Microbiol Ecol 42:1-14

Rieman L, Azam F (2002) Widespread N-acetyl- D-glucosamine uptake among pelagic marine bacteria and its ecological implications. Appl Environ Microbiol 68:5554-5562

Sala MM, Güde H (2004) Ectoenzymatic activities and heterotrophic bacteria decomposing detritus. Arch Hydrobiol 160:289-303

Editorial responsibility: Otto Kinne (Editor-in-Chief), Oldendorf/Luhe, Germany
Sala MM, Karner M, Arin L, Marrasé C (2001) Measurement of ectoenzyme activities as an indication of inorganic nutrient imbalance in microbial communities. Aquat Microb Ecol 23:301-311

Schultz GE, Ducklow HW (2000) Changes in bacterioplankton metabolic capabilities along a salinity gradient in the York River Estuary, Virginia, USA. Aquat Microb Ecol 22: 163-174

Sinsabaugh RL, Foreman CM (2001) Activity profiles of bacterioplankton in a eutrophic river. Freshw Biol 46:1239-1249

Stoecker DK, Gustafson DE (2003) Cell-surface proteolytic activity of photosynthetic dinoflagellates. Aquat Microb Ecol 30:175-183

Tam L, Kevan PG, Trevors JT (2003) Viable bacterial biomass and functional diversity in fresh and marine waters in the Canadian Arctic. Polar Biol 26:287-294

Tan TL (1997) Biolog metabolic fingerprints for clustering marine oligotrophic bacteria from polar regions. In: Insam $\mathrm{H}$, Rangger A (eds) Microbial communities: functional versus structural approaches. Springer-Verlag, Berlin, p 161-170

Tan TL, Rüger HJ (1999) Enrichment, isolation, and Biolog metabolic fingerprints of oligotrophic bacteria from the Antarctic Ocean. Arch Hydrobiol Spec Issues Adv Limnol 54:255-272

Tupas LM, Koike DM, Karl DM, Holm-Hansen O (1994) Nitrogen metabolism by heterotrophic bacterial assemblages in Antarctic coastal waters. Polar Biol 14:195-204

Vaqué D, Guixa-Boixereu N, Gasol JM, Pedrós-Alió C (2002) Distribution of microbial biomass and importance of protists in regulating prokaryotic assemblages in three areas close to the Antarctic Peninsula in spring and summer 1995/96. Deep-Sea Res II 49:847-867

Wynn-Williams DD (1990) Ecological aspects of Antarctic microbiology. In: Marshall KC (ed) Advances in microbial ecology, Vol 11. Plenum Press, New York, p 71-146

Yentsch CS, Menzel DW (1963) A method for the determination of phytoplankton chlorophyll and phaeophytin by fluorescence. Deep-Sea Res 10:221-231

Submitted: 26 July, 2004; Accepted: December 2, 2004

Proofs received from author(s): April 25, 2005 